Whatever the reason for this excess of chronic bronchitis among the "droopers"-more prolonged and concentrated tobacco smoke exposure or differing proportions of "sidestream" and "mainstream" smoke-there seems little doubt that it is a dangerous method of smoking cigarettes involving greater risk of developing chronic bronchitis and, on the evidence of Brett and Benjamin (1968), of increased mortality from lung cancer than is the normal method.

I wish to thank Professor M. R. Alderson, formerly Director of the Regional Cancer Registration Bureau, who helped plan the investigation, and the Manchester Regional Hospital Board who allowed the staff of the Mass Radiography Service to obtain the histories and the computer section to process the information. I am particularly grateful for the care and attention to detail given by the staffs of these departments.

\section{References}

Brett, G. Z., and Benjamin, B. (1968). British Medical fournal, 3, 82. College of General Practitioners (1961). British Medical fournal, 2, 273. Doll, W. R., and Hill, A. B. (1950). British Medical fournal, 2, 1271.

General Register Office (1960). Classification of Occupations, 1960. London, H.M.S.O.

Higgins, I. T. T. (1959). British Medical fournal, 1, 325.

Lowe, C. R. (1969). British Medical fournal, 1, 463.

Reid, D. D., Anderson, D. O., Ferris, B. G., and Fletcher, C. M. (1964). British Medical fournal, 2, 1487.

Rimington, J. (1969). British fournal of Disease of the Chest, 63, 193.

Rimington, J. (1972). British Medical fournal, 2, 262.

Thurlbeck, W. M., Angus, G. E., and Pare, J. A. P. (1963). British fournal of Diseases of the Chest, 57, 73.

Todd, G. F. (editor) (1969). Statistics of Smoking in the United Kingdom. Research Paper 1, 5th edn. London, Tobacco Research Council.

U.S. Department of Health, Education and Welfare (1972). Health Consequences of Smoking. Washington, U.S. Government Printing Office.

\title{
Recovery of Adrenal Function after Substitution of Beclomethasone Dipropionate for Oral Corticosteroids
}

\author{
D. J. MABERLY, G. J. GIBSON, A. G. BUTLER
}

British Medical fournal, 1973, 1, 778-782

\section{Summary}

Of 16 steroid-dependent asthmatic patients oral treatment has been discontinued in six and reduced in four after the introduction of beclomethasone dipropionate. Substitution of inhaled beclomethasone for oral steroids was unsuccessful in the remaining six patients. Serial adrenal function studies in the patients whose oral treatment was discontinued showed progressive recovery, and five out of six had a normal response to tetracosactrin stimulation after two months.

\section{Introduction}

Various attempts have been made to treat asthma by inhalation of steroids in order to obviate the suppression of adrenal function caused by systemic therapy. Inhalation of dexamethasone, hitherto the most widely used steroid aerosol, has, however, been shown to cause adrenal suppression (Linder, 1964).

Beclomethasone dipropionate is a synthetic steroid which has been in general use for some years as local treatment for various skin disorders. In contrast to other topical steroids which appear to be absorbed through the skin to an extent sufficient to produce adrenal suppression (Scoggins and Kliman, 1965), Raffle and Frain-Bell (1967) showed that there was no fall in morning levels of plasma cortisol in patients treated with topical beclomethasone dipropionate. This finding prompted studies of the possible benefits of inhaled beclomethasone in asthma, but the experience of different investigators has so far been mixed. Morrow Brown et al. (1972) showed

\footnotetext{
Department of Medicine, Royal Postgraduate Medical School and Hammersmith Hospital, London W12

D. I. MABERLY, M.R.C.P., M.R.A.C.P., Research Fellow

G. J. GIBSON, B.SC., M.R.C.P., Registrar

Allen and Hanbury's Ltd., Ware, Hertfordshire

A. G. BUTLER, B.Sc., Senior Clinical Trials Officer
}

no evidence of adrenal suppression in asthmatic patients after changing treatment from oral steroids to inhaled beclomethasone but no data were presented on adrenal function before the change, nor was there any biochemical evidence of progressive adrenal recovery. Both Clark (1972) and Lal et al. (1972) showed increases in resting morning cortisol concentrations after changing from systemic steroids to beclomethasone, but some of Clark's patients seemed to have had subnormal responses to tetracosactrin at varying intervals after oral steroids were stopped. Most of the steroid-dependent patients in these studies were satisfactorily transferred to maintenance treatment with beclomethasone in a dose between 300 and $600 \mu \mathrm{g}$ a day. Choo-Kang et al. (1972), however, were unable to control their patients' symptoms on 400 $\mu \mathrm{g}$ of beclomethasone daily. Even with $2 \mathrm{mg}$ a day they found that control was still less satisfactory than with oral steroids, and there was also evidence of suppression of adrenal function.

In this paper we report the effects of substituting inhaled beclomethasone dipropionate for oral steroids in 16 steroiddependent asthmatic patients whose adrenal function was assessed at regular intervals.

\section{Methods}

The clinical characteristics of the 16 patients are shown in table I. All had been on continuous steroid therapy for over two years, 15 of them taking a usual daily dose of $10 \mathrm{mg}$ prednisone or more. These patients were chosen because they were well known to us, their asthma was relatively stable, most of them were experiencing troublesome steroid side effects, and several attempts at withdrawal had proved unsuccessful.

Ventilatory function was assessed by twice-daily readings by the patients of their own peak expiratory flow (PEF) and by measurement at each clinic visit of the forced expired volume in one second $\left(\mathrm{FEV}_{1}\right)$ and vital capacity (VC). Data were collected for four weeks before starting beclomethasone.

The beclomethasone was given by metered aerosol delivering $50 \mu \mathrm{g}$ per puff, initially in a dose of $200 \mu \mathrm{g}$ twice daily. This was later changed to $100 \mu \mathrm{g}$ four times a day or $150 \mu \mathrm{g}$ four times a day in some cases. The patients were in- 
TABLE I-Details of Treatment and Spirometry before Trial with Beclomethasone

\begin{tabular}{|c|c|c|c|c|c|c|c|c|c|}
\hline \multirow{2}{*}{ Case No. } & \multirow{2}{*}{ Sex } & \multirow{2}{*}{$\begin{array}{l}\text { Age in } \\
\text { Years }\end{array}$} & \multirow{2}{*}{$\begin{array}{l}\text { Duration of Steroid } \\
\text { Therapy (Years) }\end{array}$} & \multirow{2}{*}{$\begin{array}{l}\text { Usual Daily Dose } \\
\text { of Prednisone or } \\
\text { Equivalent (mg)* }\end{array}$} & \multicolumn{2}{|c|}{$\begin{array}{l}\text { Highest Spirometric } \\
\text { Value Recorded* }\end{array}$} & \multicolumn{2}{|c|}{$\begin{array}{l}\text { Lowest Spirometric } \\
\text { Value Redorded* }\end{array}$} & \multirow{2}{*}{$\begin{array}{c}\text { Evidence of } \\
\text { Extrinsic Sensitivity }\end{array}$} \\
\hline & & & & & $\mathrm{FEV}_{1}$ & VC & $\mathrm{FEV}_{2}$ & VC & \\
\hline $\begin{array}{r}1 \\
2 \\
3 \\
4 \\
5 \\
6 \\
7 \\
8 \\
9 \\
10 \\
11 \\
12 \\
13 \\
14 \\
15 \\
16\end{array}$ & $\begin{array}{l}\text { F. } \\
\text { F. } \\
\text { M. } \\
\text { M. } \\
\text { M. } \\
\text { F. } \\
\text { M. } \\
\text { M. } \\
\text { M. } \\
\text { F. } \\
\text { F. } \\
\text { M. } \\
\text { F. } \\
\text { M. } \\
\text { M. } \\
\text { M. }\end{array}$ & $\begin{array}{l}61 \\
68 \\
56 \\
59 \\
53 \\
45 \\
54 \\
70 \\
69 \\
43 \\
57 \\
61 \\
25 \\
29 \\
30 \\
62\end{array}$ & $\begin{array}{r}7 \\
10 \\
14 \\
5 \\
4 \\
13 \\
2 \\
6 \\
4 \\
11 \\
15 \\
4 \\
10 \\
5 \\
4 \\
5\end{array}$ & $\begin{array}{l}10 \\
5 \\
10 \\
10 \\
15 \\
10 \\
17 \cdot 5 \\
10 \\
20 \\
10 \\
20 \\
15 \\
12.5 \\
10 \\
10 \\
10\end{array}$ & $\begin{array}{l}1.8 \\
1.0 \\
2.1 \\
2.1 \\
2.3 \\
1.1 \\
1.9 \\
2.3 \\
1.2 \\
1.3 \\
0.9 \\
3.0 \\
2.2 \\
1.4 \\
4.2 \\
1.2\end{array}$ & $\begin{array}{l}3.0 \\
2.0 \\
4.0 \\
3.9 \\
3.6 \\
3.1 \\
3.7 \\
3.5 \\
3.2 \\
3.3 \\
1.7 \\
4.1 \\
2.8 \\
4.1 \\
4.9 \\
2.6\end{array}$ & $\begin{array}{l}0.9 \\
0.8 \\
0.4 \\
1.4 \\
1.2 \\
0.5 \\
0.8 \\
1.4 \\
0.4 \\
0.9 \\
0.5 \\
1.2 \\
1.3 \\
1.1 \\
1.2 \\
0.5\end{array}$ & $\begin{array}{l}2.2 \\
1.7 \\
1.1 \\
3.0 \\
2.9 \\
1.5 \\
2.5 \\
2.6 \\
0.7 \\
2.4 \\
1.2 \\
3.3 \\
2.1 \\
2.7 \\
2.4 \\
1.4\end{array}$ & $\begin{array}{l} \pm \\
+ \\
\pm \\
+ \\
\pm \\
\pm \\
\pm \\
\pm \\
\pm \\
\pm \\
\pm\end{array}$ \\
\hline
\end{tabular}

* Over 12 months before start of trial.

TABLE II-Treatment Regimens and Mean Peak Expiratory Flow for Patients in Groups 1 and 2 Before and After Reduction of Oral Steroids

\begin{tabular}{|c|c|c|c|c|c|c|c|}
\hline \multirow{3}{*}{ Case No. } & \multirow{2}{*}{\multicolumn{2}{|c|}{$\begin{array}{l}\text { Daily Dose of Prednisone } \\
\text { or Equivalent (mg) }\end{array}$}} & \multirow{3}{*}{$\begin{array}{c}\text { Daily Dose of } \\
\text { Beclomethasone } \\
\text { Dipropionate }(\mu \mathrm{g})\end{array}$} & \multicolumn{4}{|c|}{ Mean PEF (1./min) } \\
\hline & & & & \multicolumn{2}{|c|}{ Control } & \multicolumn{2}{|c|}{ Trial Period } \\
\hline & Initial & Final & & a.m. & p.m. & a.m. & p.m. \\
\hline $\begin{array}{r}1 \\
2 \\
3 \\
4 \\
5 \\
6 \\
7 \\
8 \\
9 \\
10\end{array}$ & $\begin{array}{l}10 \\
5 \\
10 \\
10 \\
15 \\
10 \\
17 \cdot 5 \\
10 \\
20 \\
10\end{array}$ & $\begin{array}{l}0 \\
0 \\
0 \\
0 \\
0 \\
0 \\
7 \cdot 5 \\
5 \\
7 \cdot 5 \\
5\end{array}$ & $\begin{array}{l}400 \\
400 \\
400 \\
400 \\
600 \\
400 \\
600 \\
400 \\
600 \\
600\end{array}$ & $\begin{array}{l}145 \\
120 \\
294 \\
263 \\
136 \\
131 \\
198 \\
248 \\
120 \\
113\end{array}$ & $\begin{array}{r}155 \\
130 \\
352 \\
307 \\
148 \\
135 \\
239 \\
257 \\
157 \\
99\end{array}$ & $\begin{array}{r}160 \\
137 \\
359 \\
233 \\
146 \\
162 \\
225 \\
235 \\
98 \\
104\end{array}$ & $\begin{array}{l}168 \\
162 \\
393 \\
263 \\
155 \\
160 \\
264 \\
251 \\
153 \\
110\end{array}$ \\
\hline & & & Group mean values & 177 & 198 & 186 & 208 \\
\hline
\end{tabular}

structed gradually to reduce their oral steroids over a period of one to two weeks. Where deterioration of symptoms and ventilatory function occurred this plan had to be modified. In some patients several attempts at discontinuing oral steroids were made before establishing the patient on a lower dose. In others no reduction of oral steroids could be maintained and the trial of beclomethasone had to be abandoned. In the patients whose oral steroids were reduced or stopped further data on ventilatory function were collected for a period of at least the first four weeks for comparison with the control period. Previous treatment with bronchodilator tablets or disodium cromoglycate was continued; the patients were allowed to use their bronchodilator aerosol as often as necessary. In the patients whose oral steroid was stopped attempts were later made to withdraw beclomethasone.

Adrenal function was assessed by tetracosactrin stimulation tests before starting beclomethasone and one and two months after discontinuing oral steroids or after the establishment of a lower maintenance dose. When possible further tests were done four months after oral steroids had been stopped. Patients whose oral steroid dose was unaltered at the end of the trial had only two tetracosactrin tests-before and four months after starting beclomethasone.

Tetracosactrin tests were performed between 9 and 10 a.m. and at least 12 hours after the last dose of oral steroid had been taken (except in two instances; see below). Blood was drawn for plasma cortisol estimation before and 30 minutes after an injection of $0.25 \mathrm{mg}$ tetracosactrin (Synacthen) and the plasma was stored at $-20^{\circ} \mathrm{C}$ until the assay was carried out. Plasma cortisol was assayed by the competitive protein binding method of Murphy (1967) using standard solutions made up from cortisol powder supplied by Glaxo Laboratories. The mean of the differences of duplicate measurements of plasma samples was $1.4 \mu \mathrm{g} / 100 \mathrm{ml}$ with a standard deviation of the differences of $\pm 1.45 \mu \mathrm{g} / 100 \mathrm{ml}$. The criteria of normality for the tetracosactrin test results were the presence of at least two of the following: a resting plasma level of more than $6 \mu \mathrm{g} / 100 \mathrm{ml}$, a poststimulation level at 30 minutes of more than $18 \mu \mathrm{g} / 100 \mathrm{ml}$, and a rise of more than $7 \mu \mathrm{g} / 100 \mathrm{ml}$ (Greig et al., 1969).

\section{Results}

The criteria for satisfactory control of asthma used in this study were no deterioration in symptoms and no significant difference between peak flow readings during the four-week run-in period and those during the first four-week period without oral steroid or after establishing a constant reduced dose. On this basis the 16 patients were divided into three groups. Group 1 comprised six patients (cases 1-6) in whom is proved possible to withdraw oral steroids rapidly without any deterioration in their asthma. In group 2 (cases 7-10) control was attained on a lower dose of oral steroid after at least two attempts at complete withdrawal had provoked an exacerbation. The six patients in group 3 (cases 11-16) could not be symptomatically controlled by a combination of beclomethasone and a reduced dose of oral steroid.

The initial and final dosage regimens together with the mean morning and evening peak flow readings during the two four-week periods are shown in table II for each patient in groups 1 and 2. There was clearly no difference in mean PEF between the two periods. A typical example of a patient in group 1 is shown in fig. 1. The PEF readings remained stable despite a rapid reduction of oral steroid, and the reduction in bronchodilator aerosol usage after starting beclomethasone suggests better control of asthmatic symptoms. By contrast, fig. 2 shows an example of a patient in group 3. Here there is clear evidence of a deterioration in ventilatory function, with reductions in PEF and $\mathrm{FEV}_{1}$ on both occasions that prednisone was withdrawn.

For patients in groups 1 and 2 the change in mean peak flow readings during the trial was plotted against the reduc- 


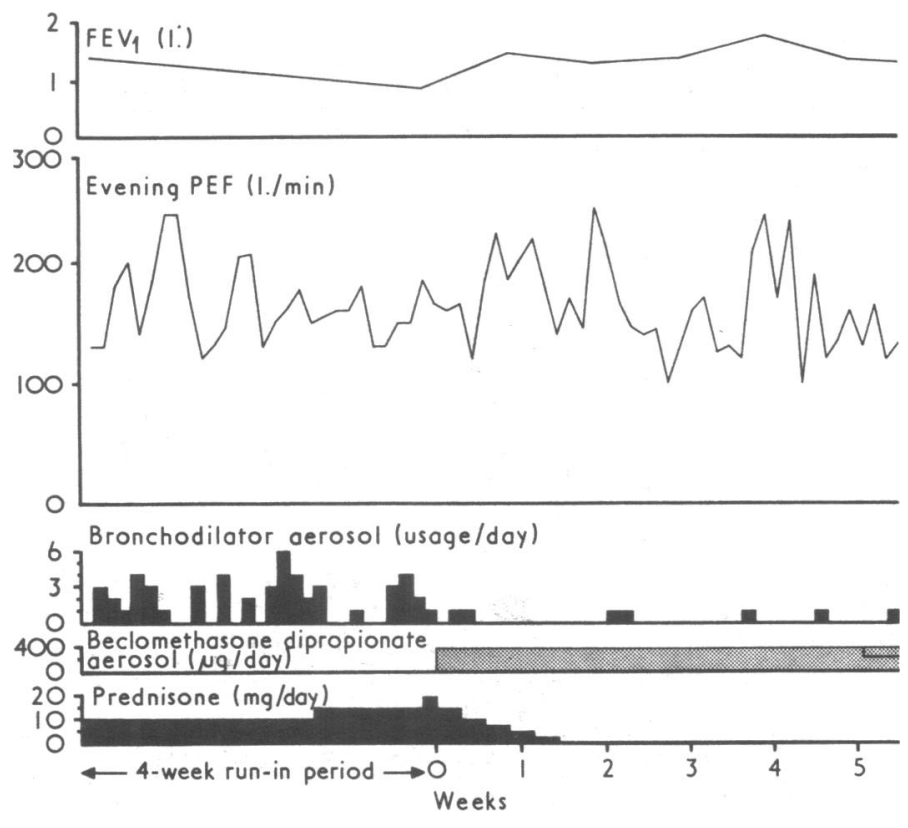

FIG. 1-Relation of pulmonary function to therapy in case 1 (group 1).

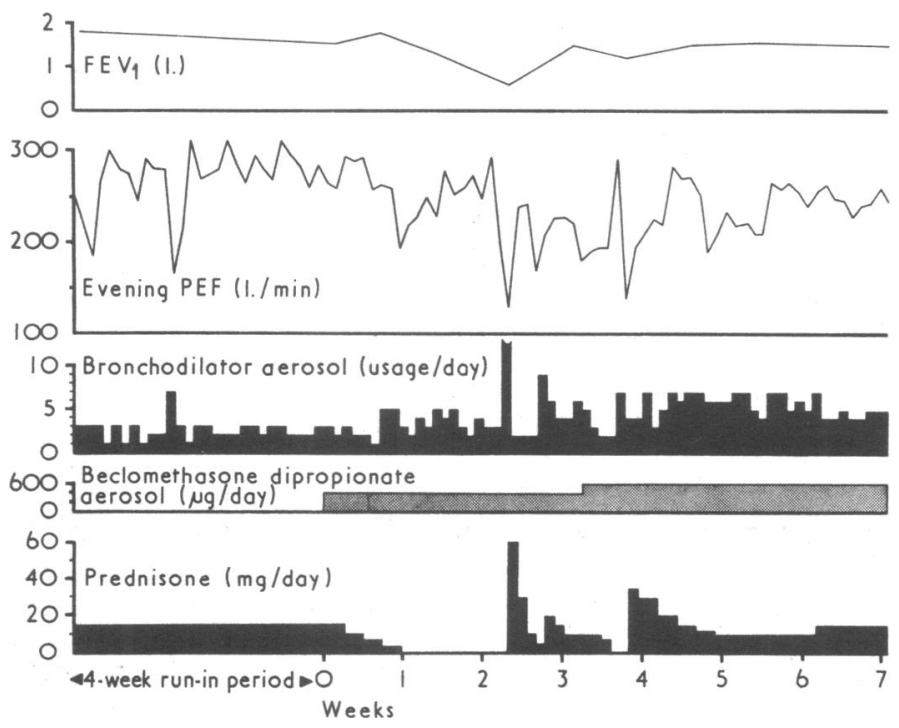

FIG. 2--Relation of pulmonary function to therapy in case 13 (group 3).

tion in oral steroid dose; as shown in fig. 3, there was clearly no relationship.

Attempts were later made to withdraw beclomethasone in four of the six patients in group 1. In each case deterioration in symptoms and ventilatory function occurred. The minimum daily dose of beclomethasone on which any of the patients was controlled was $200 \mu \mathrm{g}$.

The initial adrenal function studies on all 16 patients in this study showed low resting plasma cortisol levels with grossly subnormal (or absent) responses to tetracosactrin. The results of serial tests are shown in fig. 4. Patients in group 1 showed progressive increases in resting plasma cortisol and in responses to tetracosactrin. One month after oral steroids had been stopped four of the six gave normal results and at two months five were normal. The response of the sixth patient, although increased, was still abnormal at four months and remained abnormal despite a course of depot tetracosactrin. The responses of the patients in group 2, all of whom were taking a daily dose of prednisone of 5 or $7.5 \mathrm{mg}$, were all

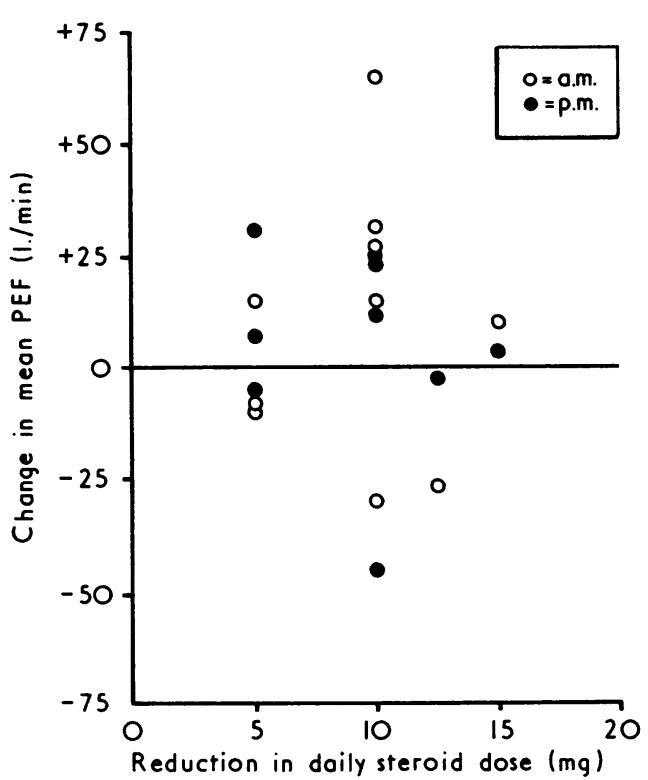

FIG. 3-Plot of change in mean PEF against reduction in oral steroid dose for patients in groups 1 and 2 .

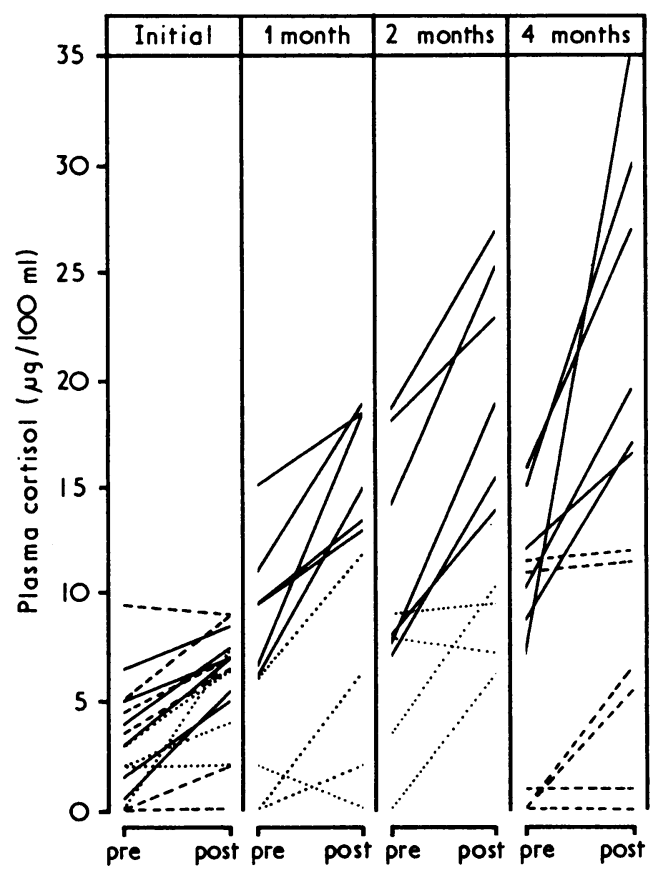

FIG. 4-Results of serial tetracosactrin stimulation tests in all patients. Solid lines represent group 1 , dotted lines group 2, and dashed lines group 3.

still abnormal at two months after the establishment of this dose. (This period represents at least four months after the first reduction of steroid dosage.)

The responses of the patients in group 3 were repeated only at four months and all remained abnormal. Two of these patients appeared to have high resting levels; in both instances it had not been possible for the patient to omit prednisone for 12 hours before the test, which would have accounted for part of the measured level.

Side effects experienced by patients in groups 1 and 2 during reduction of oral steroids are noted in table III. Nine of the ten patients noted systemic symptoms suggestive of steroid withdrawal (nausea, vomiting, anorexia, malaise, 
TABLE III-Symptoms noted by Patients in Groups 1 and 2 after Reduction of Oral Steroid Dose

\begin{tabular}{l|c|c|c|c|c}
\hline Case No. & $\begin{array}{c}\text { Malaise } \\
\text { and } \\
\text { Anorexia }\end{array}$ & $\begin{array}{c}\text { Nausea } \\
\text { or } \\
\text { Vomiting }\end{array}$ & $\begin{array}{c}\text { Muscle } \\
\text { and Joint } \\
\text { Pains }\end{array}$ & $\begin{array}{c}\text { Rhinitis } \\
\text { or } \\
\text { Hay Fever }\end{array}$ & Eczema \\
\hline 1 & + & & + & + & + \\
2 & + & + & + & + & + \\
$\mathbf{4}$ & + & + & + & + & + \\
$\mathbf{6}$ & + & + & + & + & + \\
7 & + & + & + & & + \\
$\mathbf{9}$ & + & & + & & + \\
\hline
\end{tabular}

muscle and joint pains), while six suffered exacerbations of other atopic conditions, such as seasonal or perennial rhinitis and eczema.

\section{Discussion}

Out of 16 patients with asthma of moderate or severe degree good control was maintained in six by the use of inhaled beclomethasone alone and in a further four by a combination of beclomethasone with a reduced dose of oral steroid. It might have been expected that the patients most likely to have benefited from beclomethasone would have been those least severely affected, but this did not appear to be the case, as the change in mean PEF was not related to prednisone dosage (fig. 3). In addition only three patients (cases 12, 13, and 15) had recorded normal spirometric figures at some time during the 12 months preceding the trial, and these were all classed as group 3 (failures).

Our results contrast with those of Choo-Kang et al. (1972), who were unable to achieve adequate control of asthma with $400 \mu \mathrm{g}$ of beclomethasone dipropionate daily. Although no data on these patients were presented the authors proceeded to compare the effects of inhaled beclomethasone in a much higher dose of $2 \mathrm{mg}$ daily for one week with oral prednisolone $20 \mathrm{mg}$ daily in a subsequent week. They concluded that beclomethasone offered no advantage because of evidence of adrenal suppression and because prednisolone appeared to further improve the $\mathrm{FEV}_{1}$ of those patients who responded to beclomethasone. Their study was, however, based on only seven patients with "airways obstruction," three of whom showed no response to either drug. Two of the remaining four responded well to beclomethasone; their subsequent further improvement on prednisolone may have been a continuation of the steroid response, which often takes longer than one week to reach its maximum. This work does, however, show that inhaled beclomethasone may be significantly absorbed when given in these high doses.

Clark (1972) studied eight asthmatic patients who were transferred from oral prednisolone (in a dose of $10-15 \mathrm{mg}$ daily) to inhaled beclomethasone $(400 \mu \mathrm{g}$ daily) without any deterioration in spirometry in the initial stages. Although control was not fully maintained in three of these, all the patients were able to stop continuous oral steroids. Successful transfer from oral prednisolone to inhaled beclomethasone was also achieved by Lal et al. (1972) in a double-blind study of 38 patients without any deterioration in mean PEF. Their patients were, however, on lower maintenance steroid doses (up to $7.5 \mathrm{mg}$ prednisolone daily) than ours and, although no individual figures of ventilatory function were given, nine patients were symptomatically worse after transfer.

The reasons for failure of beclomethasone to give adequate control in some patients are not at all clear, though some pointers can be given. In our study one of the patients in group 3 developed extensive and incapacitating eczema when his prednisone dosage was reduced below a maintenance dose of $10 \mathrm{mg}$ per day, and this rather than deterioration of asthma was the reason for discontinuance in his case. Beclomethasone in this trial was administered by a finger-activated pressurized aerosol, and at least one patient failing to respond was totally unable to co-ordinate activation of the aerosol with inspiration; perhaps use of a breath-activated inhaler would obviate this difficulty. Very little is known of the bronchial metabolism of beclomethasone, and the possibility of its variability between individuals accounting for failure of the remaining four patients to respond must remain speculative. A further explanation might be an inability of the adrenal glands to recover, but in the face of continuing adrenal suppression by oral treatment this was impossible to assess.

The development of symptoms suggestive of steroid withdrawal together with the recrudescence of rhinitis or eczema suggests that there was no significant absorption of beclomethasone in the dosage used. The progressive increase in tetracosactrin response in the patients in group 1, reaching normal levels in five out of six, is good evidence both of absence of adrenal suppression by inhaled beclomethasone and of the recovery of adrenal function even after suppression by prednisone for up to 14 years. No tests of the integrity of the complete hypothalamo-pituitary-adrenal axis were, however, performed.

The failure of the patients in group 2 to show evidence of adrenal recovery, despite a reduction of oral steroids to levels of 5 to $7.5 \mathrm{mg}$ per day, is disappointing. Although it might be expected that at this dosage level some recoverv of adrenal function would have occurred (Westerhof et al., 1970) the rate of recovery apoeared to be largelv related to the preceding steroid dose (Westerhof et al., 1972), and longer follow-up is necessary. This failure of recovery does not negate the probable beneficial effects of a lower dose in preventing the occurence of other side effects of long-term systemic steroids.

This study disclosed several practical points regarding administration of beclomethasone, some of which have been noted by others (Morrow Brown et al.. 1972). Svstemic effects of steroid withdrawal are almost the rule and patients need to be warned of these in advance. Thev rarelv last longer than two or three weeks: however, the patient in group 1 whose adrenal function remained subnormal noted persistent muscular aches: additional specific treatment had to be used for patients with troublesome rhinitis and eczema.

It is our experience and that of others (Lal et al., 1972; Morrow Brown et al. 1972) that even after several vears of treatment oral steroids can be tailed off over a matter of several days, provided that the patient is closely supervised and is instructed to report anv symntoms of acute arrenal insufficiency. Four-times daily administration of beclomethasone seems to be tolerated better than an equal dailv dose given less frequently; the use of a conventional bronchodilator aerosol before inhalation of beclomethasone may facilitate its distribution and seemed to imbrove control in some patients. Severe exacerbations of asthma reauired oral or svstemic steroids for their control, and at present beclomethasone has no vlace in the management of the severe asthmatic attack.

We conclude that inhaled beclomethasone dipropionate is likelv to prove a valuable agent in the management of many patients with chronic asthma but it needs to be tried on an individual basis with adequate assessment of ventilatory function.

We wish to thank Dr. C. M. Fletcher and Dr. N. B. Pride for advice, encouragement, and permission to study patients under their care. Beclomethasone dipropionate was supplied by Messrs. Allen and Hanburys.

\section{References}

Brown, H. M., Storey, G., and George, W. H. S. (1972). British Medical Fournal, 1, 585

(1972). British fournal of Diseases of the Chest, 66, 101. 
Clark, T. J. H. (1972). Lancet, 1, 1361.

Greig, W. R., Maxweil, J. D., Boyle, J. A., Lindsay, R. M., and Browning, M. C. K. (1969). Postgraduate Medical fournal, 45, 307.

Lal, S., Harris, D. M., Bhalla, K. K., Singhal, S. N., and Butler, A. G. (1972). British Medical fournal, 3, 314.

Linder, W. R. (1964). Archives of Internal Medicine, 113, 655.

Murphy, B. E. P. (1967). Journal of Clinical Endocrinology and Metabolism, 23, 973 . Raffle, E. J., and Frain-Bell, W. (1967). British fournal of Dermatology, 79,

Scoggins, R. B., and Kliman, B. (1965). New England fournal of Medicine, 273, 831 .

Westerhof, L., van Ditmars, M. J., der Kinderen, P. J., Thijssen, J. H. H., and Schwartz, F. (1970). British Medical fournal, 4, 534.

Westerhof, L., van Ditmars, M. J., der Kinderen, P. J., Thijssen, J. H. H., and Schwartz, F. (1972). British Medical fournal, 2, 195.

\section{MEDICAL MEMORANDA}

\section{Behçet's Disease with Decreased Fibrinolysis and Superior Vena Caval Occlusion}

\section{T. CHAJEK, M. FAINARU}

British Medical Yournal, 1973, 1, 782-783

Thrombophlebitis is a recognized manifestation of Behçet's disease but thrombotic occlusion of large vessels is rare (Haim et al., 1971; Enoch et al., 1968; Kansu et al., 1972). We report here two cases with superior vena caval obstruction and defective fibrinolysis which were treated successfully with fibrinolytic agents.

\section{Case 1}

A 30-year-old Arab man was admitted to hospital because of increasing swelling of the face and neck over the past six weeks. He had suffered from recurrent oral and scrotal ulcers for two years, and 18 months previously he had developed superficial thrombophlebitis of the left leg. Three months after that he had noticed engorgement of the superficial veins of his left upper limb. Ten months later a painful swelling in the right cervical region developed, spreading rapidly to the entire neck and causing puffiness of the face.

On admission the classical signs of superior vena caval obstruction, with prominent venous collaterals over the chest and abdomen, were present. Ophthalmological examination showed evidence of uveitis and pronounced dilatation of the retinal veins. The right supraclavicular space was occupied by a dusky, painful mass, and there were several superficial oral and scrotal ulcers. The heart, lungs, abdomen, and nervous system were normal. Total serum protein was $7 \cdot 2 \mathrm{~g} / 100 \mathrm{ml}$, with a slight increase in alpha 2 globulin fraction $(16.8 \%)$. No cryoglobulin was detected. A chest radiograph showed widening of the superior mediastinum. A right brachial venogram showed widening and obstruction of the subclavian vein, very dilated axillary and brachial veins, and prominent venous collaterals (see fig.). Bone marrow aspirate showed mild eosinophilia and plasmacytosis. Biopsy of material from a scrotal ulcer showed nonspecific inflammation. Lymph node and liver biopsy were normal. The supraclavicular mass was found on exploration to be a thrombosis of the large veins, which extended into the mediastinum. No tumour or inflammatory process was found. Biopsy of material from one of the thrombotic veins showed chronic inflammation of the wall with a large organized adherent thrombus.

The results of coagulation studies are shown in the table. The clotting time, prothrombin time, partial thromboplastin time, factor II, V, VII, and X, and the platelet aggregation were all within normal limits on admission.

\footnotetext{
Department of Medicine B, Hadassah University Hospital,
Jerusalem, Israel

While in hospital the patient developed erythema nodosum-like lesions on both arms, red papules and pustules after each needle prick, and thrombophlebitis after every venepuncture. He was given Varidase 12 tablets daily by mouth (each tablet containing streptokinase $10,000 \mathrm{U}$ and streptodornase 2,500 U). After 48 hours the general condition greatly improved, the swelling of the head and neck decreased, and the supraclavicular mass disappeared. After 14 days Varidase treatment was discontinued for one week: the patient's condition deteriorated and fibrinolysis decreased. When treatment was resumed there was again a clinical remission and plasma fibrinolytic activity increased. The patient was discharged on a maintenance dose of 12 tablets of Varidase daily, and 16 months later he was well and showed no signs of thrombophlebitis.

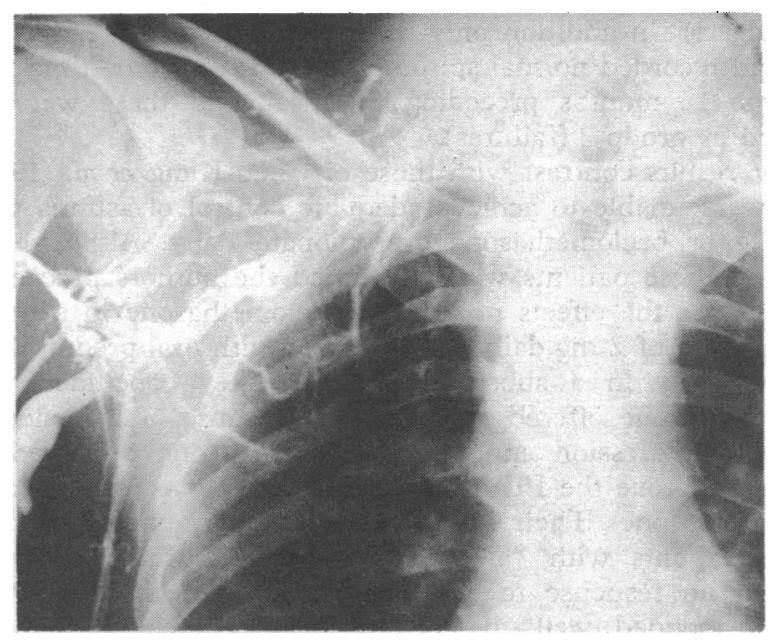

Right brachia! venogram in case 1.

\section{Case 2}

A 22-year-old Arab man was admitted because of fever and progressive swelling of the face of four weeks' duration. For the past four years he had had recurrent aphthous stomatitis, scrotal ulcers, and conjunctivitis accompanied by febrile episodes. Nine months before admission he had noticed periodic symmetrical swelling of the neck and dilatation of the superficial veins of the chest and abdomen. $\mathrm{He}$ presented the classical signs of superior vena caval occlusion. He had superficial ulcers, 5-7 $\mathrm{mm}$ in diameter, on both lips, tongue, and scrotum. Chest radiography showed widening of the right superior mediastinum with some opácity of the right lung parenchyma and a small amount of fluid in the right pleural cavity. The results of relevant coagulation studies are given in the table. The other tests were within normal limits.

Treatment was with intravenous fluids. Severe thrombophlebitis developed at the site of one of the infusions, and extended into the axilla. Streptokinase $300,000 \mathrm{U}$ infused over the first $\mathbf{2 4}$ hours produced a dramatic improvement of the thrombophlebitis and correction of the fibrinolytic defect (see table). Treatment was continued with oral Varidase, and six months later he was well, except for occasional superficial oral ulcers, and the euglobulin lysis time was within normal limits. 